Jurnal Professional FIS UNIVED Vol. 2 No.2 Desember 2015

\title{
HUBUNGAN KARAKTERISTIK PETANI DENGAN EFEKTIVITAS KOMUNIKASI PENYULUHAN PERTANIAN DALAM PROGRAM SL-PTT (Kasus Kelompok Tani di Kecamatan Kerkap Kabupaten Bengkulu Utara)
}

\author{
Oleh: \\ SRI NARTI \\ Dosen Prodi Ilmu Komunikasi Fakultas Ilmu-Ilmu Sosial Unived Bengkulu
}

\begin{abstract}
Elucidator role on SL-PTT program is really important. As spreading the information in elucidation activity was directly doing to the farmers. The elucidator prosecuted not only to be able to spread the information about SL-PTT but it should helps the farmer to analyze the happening situation, enhance their knowledge about SL-PTT, and develop their insight toward the problem too. The purposes of this research are to describe about communication effectiveness between elucidator with the farmer and acknowledge how far the relationship between farmer characteristic and communication effectiveness on SL-PTT program. This research use quantitative-descriptive with the population of farmworker group in Kerkap Subdistrict, Bengkulu Utara Regency. The sample-taking of 90 people from farmworker group doing by using Slovin's formula. Determine the amount sample per farmworker group using Proportionale Random Sampling and Accidental Sampling used for choosing sample per each group of farmworker. Data-gathering was doing by gone round a set of question toward the respondent to be answered through questionnaire. And the data analysis is using correlation Chi-Square, a correlation test that has fuction to observe relation between two variable.

The result of this research shows that the communication effectiveness of farming elucidation on SL-PTT program in Kerkap, Bengkulu Utara, rated with effective enough. Age variable is significant related with communication effectiveness between elucidator and farmer. Education level is significant related with communication effectiveness between elucidator and farmer. Landmass is significant related with communication effectiveness between elucidator and farmer. Media consumption is significant related with communication effectiveness between elucidator and farmer. Too, the frequency to join elucidation is significant related with communication effectiveness between elucidator and farmer. And the most dominant farmer's characteristic that related to communication efectiveness is the farmer education level and frequency following the guidance.
\end{abstract}

\section{Keyword: Communication Effectiveness, Farmer Characteristic}

\section{PENDAHULUAN}

Indonesia adalah negara agraris sehingga pertanian merupakan sektor penting dalam meningkatkan kesejahteraan kehidupan masyarakat. Saat ini, Indonesia sedang mengupayakan pengembangan dan penerapan pertanian organik dalam mewujudkan pertanian modern menuju pertanian mandiri dan sejahtera. Pembangunan pertanian ini, dapat diterapkan dengan ilmu pengetahuan dan teknologi di bidang pertanian yang didukung oleh peranan sumber daya manusia (SDM) dan sumberdaya alam (SDA) yang ada. Sejak Revolusi Hijau tahun enam puluhan perkembangan penggunaan teknologi 
pertanian oleh petani padi sangat pesat dalam upaya meningkatkan kuantitas dan kualitas produksi seiring dengan kemajuan ilmu pengetahuan dan teknologi (IPTEK) untuk memenuhi kebutuhan beras yang terus bertambah (Adjid, 2001:12).

Sepuluh tahun terakhir, kondisi sektor pertanian Indonesia terus menurun misalnya dari segi produksi padi pada tahun 2010, Badan Pusat Statistik (BPS) menyatakan bahwa produksi padi sebesar 66.469.394 ton dengan rata-rata produktivitas mencapai $50,15 \mathrm{Kw} / \mathrm{Ha}$ dan luas lahan panen mencapai 13. $253.450 \mathrm{Ha}$. Awal tahun 2011 total luas areal padi di Indonesia mencapai 12.879.039 $\mathrm{Ha}$, produksi padi menurun hanya mencapai 64.329.329 ton dengan produktivitas 49 $\mathrm{Kw} / \mathrm{Ha}$, jauh dari standar yang diharapkan yakni 100 kwintal per hektar. Bila dilihat dari jumlah rumah tangga tani, data dari Badan Pusat Statistik Tahun 2013 mencatat jumlah tenaga kerja di sektor pertanian dalam tiga tahun terakhir terus mengalami penurunan. Februari 2012 jumlah tenaga kerja di sektor tersebut masih tercatat 42, 36 juta orang, maka pada Februari 2013 jumlahnya menurun menjadi 41, 11 juta orang. Penurunan berlanjut pada tahun 2014, berdasarkan rilis Badan Pusat Statistik, jumlah tenaga kerja di sektor pertanian per Februari 2014 hanya berjumlah 40, 83 juta orang.

Upaya pembangunan pertanian berhubungan erat dengan pengembangan sumber daya manusia terutama petani sebagai pelaku utama. Sumber daya manusia tersebut dihasilkan dari kegiatan penyuluhan pertanian. Peraturan sistem penyuluhan di Indonesia tertuang dalam Undang-undang nomor 16 tahun 2006 Tentang Sistem Penyuluhan Pertanian, Perikanan, dan Kehutanan (SP3K). Bab I pasal 1 disebutkan bahwa kegiatan penyuluhan pertanian selain ditujukan sebagai upaya untuk meningkatkan produktivitas, efisiensi usaha, dan pendapatan juga menekankan pada peningkatan kesejahteraan, serta kesadaran dalam pelestarian lingkungan hidup.
Sejalan dengan perkembangan ilmu pengetahuan dan teknologi, Departemen Pertanian meluncurkan Program Sekolah Lapang Pengelolaan Tanaman Terpadu (SLPTT) yang merupakan program nasional pemerintah Indonesia sejak tahun 2008. Program SL-PTT memiliki tujuan utama untuk mempercepat peralihan teknologi dari peneliti dan narasumber kemudian berlangsung secara alamiah dari alumni SLPTT kepada petani lainnya dan sampai akhirnya tercapai peningkatan kemandirian pangan nasional khususnya padi, pendapatan dan kesejahteraan petani.

Kegiatan SL-PTT di Kecamatan Kerkap Kabupaten Bengkulu Utara dimulai sejak tahun 2009. Pelaksanaan SL-PTT diadakan secara bertahap dan bergantian dari 33 kelompok tani yang ada dengan kawasan yang telah disepakati oleh petani di Kecamatan Kerkap. Kegiatan SL-PTT ini dikoordinasi oleh Dinas Pertanian Kabupaten Bengkulu Utara dengan melibatkan Badan Penyuluhan Pertanian (BPP) Kecamatan. SLPTT dipandu oleh Penyuluh Pertanian dan peneliti (pendamping ahli) dari Provinsi.

Peran penyuluh dalam program SLPTT ini sangat penting, penyebaran informasi pada kegiatan penyuluhan pertanian dilakukan langsung bersama para petani. Penyuluh tidak hanya diamanatkan mampu menyebarluaskan informasi seputar SL-PTT saja, namun juga membantu petani dalam menganalisis situasi yang sedang dihadapi, meningkatkan pengetahuan tentang SL-PTT dan mengembangkan wawasan terhadap suatu masalah, membantu petani memutuskan pilihan yang tepat yang menurut pendapat mereka sudah optimal, meningkatkan motivasi kepada petani untuk menerapkan pilihannya, dan membantu petani untuk mampu mengevaluasi serta meningkatkan keterampilan mereka dalam membentuk pendapat dan pengambilan keputusan.

Kegiatan SL-PTT sudah berlangsung dari tahun ke tahun di Kecamatan Kerkap namun produktivitas padi masih di bawah 
target 100 kwintal per hektar, perlu upaya peningkatan produksi dan produktivitas penerapan teknologi secara terpadu. Hal ini mungkin ada hubungannya dengan komunikasi yang berlangsung antara penyuluh sebagai penyampai pesan dengan petani sebagai penerima pesannya. Komunikasi memegang kunci penting karena kegiatan penyuluhan pertanian itu sendiri adalah kegiatan komunikasi. Komunikasi dapat menentukan efektivitas kegiatan penyuluhan pertanian dan merupakan suatu alat yang digunakan dalam proses kegiatan penyuluhan SL-PTT. Efektivitas komunikasi dipengaruhi oleh banyak faktor seperti: pesan, komunikasi dan karakteristik petani. Karakteristik petani dapat berupa umur, tingkat pendidikan, luas lahan, konsumsi media, dan frekuensi mengikuti penyuluhan.

Sehubungan dengan latar permasalahan di atas, maka peneliti merasa penting untuk meneliti tentang efektivitas komunikasi antara penyuluh dengan petani dalam program SL-PTT yang peneliti anggap cenderung ada kaitannya dengan kegagalan program SL-PTT di Kecamatan Kerkap.

\section{METODOLOGI PENELITIAN}

Penelitian ini adalah penelitian deskriptif kuantitatif yang menggambarkan suatu gejala atau fenomena tertentu (Prasetyo, 2010:42). Metode survey digunakan dalam pengumpulan data karena memiliki beberapa keuntungan yaitu menghemat biaya dalam pengumpulan data, pengumpulan dan penyajian data lebih cepat, cakupan variabel lebih luas, dan akurasi yang lebih luas (Singarimbun dan Effendi, 1995:4).

Populasi pada penelitian ini adalah anggota kelompok tani di Kecamatan Kerkap Kabupaten Bengkulu Utara yang terdiri dari 33 kelompok tani yang mengikuti program SL-PTT yang berjumlah 856 orang. Penentuan jumlah sampel dalam penelitian ini dilakukan dengan rumus Slovin (Umar, 2003: 137) dan didapat 90 responden dari total populasi 856 orang. Teknik yang digunakan untuk pengambilan sampel adalah Proportionale Random Sampling yang digunakan bila populasi mempunyai anggota/unsur yang tidak homogen secara proporsional (Sugiyono, 2011: 63-64).

Berdasarkan pendapat Sugiyono (2012: 126), syarat minimum untuk dianggap memenuhi syarat validitas adalah jika $\mathrm{r} \geq$ 0,3 . Berdasarkan nilai korelasi item pertanyaan dengan item total, didapatkan bahwa seluruh pertanyaan memiliki nilai korelasi lebih besar dari 0,3 . Artinya semua pertanyaan dinyatakan valid untuk dijadikan alat ukur. Sedangkan uji reliabilitas dilakukan dengan metode Alpha Cronbach's,dimana apabila nilai Alpha Cronbach's di atas 0,7 pada taraf signifikansi 0,05 maka instrumen dinyatakan reliabel.

\section{HASIL PENELITIAN DAN PEMBAHASAN \\ Hasil Penelitian \\ Analisis Deskriptif Karakteristik Petani dengan Efektivitas Komunikasi Penyuluhan Pertanian dalam Program SL-PTT \\ Karakteristik petani}

Karakteristik petani yang diamati dalam penelitian ini adalah umur, tingkat pendidikan, luas lahan, konsumsi media, dan frekuensi mengikuti penyuluhan. Hasil penyebaran kuesioner terhadap 90 anggota kelompok tani di Kecamatan Kerkap Kabupaten Bengkulu Utara menghasilkan karakteristik petani sebagai berikut:

1. Umur

Distribusi umur responden, dikelompokkan ke dalam empat jenjang umur yaitu kelompok remaja (16-21 tahun), kelompok dewasa muda (22-39 tahun), kelompok menengah (40-63 tahun) dan kelompok tua (64-78 tahun). Berikut distribusi frekuensi umur responden berdasarkan kelompok umur tersebut: 
Tabel 1. Karakteristik responden berdasarkan umur

\begin{tabular}{|c|l|c|c|}
\hline No & Umur & $\begin{array}{c}\text { Jumlah } \\
\text { (orang) }\end{array}$ & $\begin{array}{c}\text { Frekuensi } \\
(\%)\end{array}$ \\
\hline 1 & $16-21$ tahun & 4 & 4,4 \\
\hline 2 & $22-39$ tahun & 38 & 42,2 \\
\hline 3 & $40-63$ tahun & 45 & 50 \\
\hline 4 & $64-78$ tahun & 3 & 3,3 \\
\hline \multicolumn{2}{|c|}{ Total } & 90 & 100,0 \\
\hline
\end{tabular}

Sumber: Hasil penelitian, data diolah (2015)

Berdasarkan tabel di atas diketahui bahwa responden lebih dominan pada kelompok umur menengah, disusul kelompok umur dewasa muda, lalu kelompok umur remaja. Hasil penelitian ini menunjukkan bahwa semakin cukup umur petani maka semangat dan kemampuan bekerjanya jauh lebih matang, sehingga komunikasi dalam penyuluhan dapat berlangsung secara efektif karena mereka memiliki motivasi yang cukup serta serius dalam mengikuti kegiatan SLPTT yang diberikan oleh penyuluh. Menurut Mappiare (1983:14), ada kecenderungan bagi seseorang yang berusia tiga puluh lima tahun ke atas untuk lebih memantapkan dirinya dalam bekerja, berkenaan dengan semakin tingginya biaya hidup yang perlu dikeluarkan. Hal ini menunjukkan bahwa rentang umur antara 40-63 tahun termasuk dalam kategori yang disebutkan oleh Mappiare, karena umur tiga puluh lima tahun ke atas masih tergolong pada posisi rentang umur menengah.

\section{Tingkat pendidikan}

Tingkat pendidikan responden dikelompokkan ke dalam tiga kategori: pendidikan rendah yaitu tidak tamat SD dan tamat SD, pendidikan sedang yaitu tamat SMP, dan pendidikan tinggi tamat SMASarjana. Berikut distribusi frekuensi responden berdasarkan tingkat pendidikan:
Tabel 2. Karakteristik responden berdasarkan pendidikan

\begin{tabular}{|c|c|c|c|}
\hline No & $\begin{array}{c}\text { Tingkat } \\
\text { pendidikan }\end{array}$ & $\begin{array}{c}\text { Jumlah } \\
\text { (orang) }\end{array}$ & $\begin{array}{c}\text { Frekuensi } \\
(\%)\end{array}$ \\
\hline 1 & $\begin{array}{c}\text { Tidak } \\
\text { tamat SD }\end{array}$ & 10 & 11,1 \\
\hline 2 & SD & 13 & 14,4 \\
\hline 3 & SMP & 10 & 11,1 \\
\hline 4 & SMA & 41 & 45,6 \\
\hline 5 & Sarjana & 16 & 17,8 \\
\hline & Total & 90 & 100,0 \\
\hline
\end{tabular}

Sumber: Hasil penelitian, data diolah (2015)

Berdasarkan tingkat pendidikan, mayoritas responden sebanyak 45,6\% tamat SMA, disusul $17,8 \%$ responden lulusan sarjana, 14,4\% responden tamat SD dan masing-masing $11,1 \%$ responden tamat SMP dan tidak tamat SD. Tinggi rendahnya pendidikan petani akan menanamkan sifat menuju penggunaan praktek pertanian yang lebih modern. Mereka yang berpendidikan tinggi relatif lebih cepat dalam melakukan anjuran penyuluh. Kebanyakan dari mereka yang berpendidikan tinggi ini lebih cepat mengerti dan memahami pesan-pesan yang disampaikan penyuluh dalam program SLPTT.

Umumnya pendidikan berpengaruh terhadap cara dan pola berpikir petani, sebab pendidikan merupakan suatu proses pengembangan pengetahuan, keterampilan maupun sikap petani yang dilaksanakan secara terencana, sehingga memperoleh perubahan-perubahan dalam peningkatan hidup. Semakin tinggi tingkat pendidikan seseorang, semakin berkembang pola berpikirnya sehingga dapat dengan mudah mengambil keputusan dalam melakukan sesuatu dengan baik termasuk keputusan dalam kegiatan SL-PTT.

Pendidikan formal yang ditempuh responden akan mempengaruhi pola pikirnya terhadap suatu hal. Demikian halnya pada saat teknologi yang ditawarkan, maka responden juga akan memikirkan kesesuaian antara teknologi yang terdapat dalam program tersebut baik yang berhubungan dengan lahan 
pekarangan yang dimiliki maupun keadaan sosial dimana responden tinggal. Tingkat pendidikan berpengaruh juga terhadap perubahan teknologi modern, khususnya teknologi dalam program SL-PTT. Petani yang berpendidikan tinggi lebih bisa membudidayakan padi ke arah agribisnis, bukan sekedar pemenuhan kebutuhan rumah tangga, karena pendidikan dapat mendorong tumbuhnya kreatifitas sehingga mampu menangkap peluang atau kesempatan berusaha. Sebaliknya, tingkat pendidikan yang rendah pada umumnya kurang menyenangi perubahan sehingga sikap mental untuk menambah pengetahuan khususnya ilmu pertanian berkurang dan mereka yang berpendidikan rendah, agak sulit dan memakan waktu yang relatif lama untuk mengadakan perubahan.

3. Luas lahan

Untuk mempermudah dalam menganalisis luas lahan yang dimiliki petani, maka penulis mengelompokkan luas lahan ke dalam tiga kategori yaitu: $(\leq 0,25 \mathrm{ha})$, (0,26-0,5 ha) dan ( $\geq 0,5$ ha). Untuk lebih jelasnya distribusi frekuensi luas lahan yang dimiliki petani adalah:

Tabel 3. Karakteristik responden berdasarkan luas lahan

\begin{tabular}{|l|l|c|c|}
\hline No & \multicolumn{1}{|c|}{ Luas lahan } & $\begin{array}{l}\text { Jumlah } \\
(\text { orang })\end{array}$ & $\begin{array}{c}\text { Frekuensi } \\
(\%)\end{array}$ \\
\hline 1 & $\begin{array}{l}\text { Sempit }(\leq \\
0,25 \text { ha) }\end{array}$ & 5 & 5,6 \\
\hline 2 & $\begin{array}{l}\text { Sedang }(0,26- \\
0,5 \text { ha })\end{array}$ & 18 & 20,0 \\
\hline 3 & $\begin{array}{l}\text { Luas }(\geq 0,5 \\
\text { ha) }\end{array}$ & 67 & 74,4 \\
\hline & Total & 90 & 100,0 \\
\hline
\end{tabular}

Sumber: Hasil penelitian, data diolah (2015)

Berdasarkan tabel di atas dapat dilihat bahwa luas lahan yang dimiliki petani yang menjadi responden mayoritas lebih dari setengah hektar. Hal ini menunjukkan bahwa masih banyaknya lahan yang diolah petani untuk kegiatan pertanian. Masih besarnya keinginan petani untuk ikut bergabung dalam program SL-PTT karena berpengaruh terhadap penerapan teknologi pertanian, sebab semakin luas lahan usaha tani, semakin tinggi hasil produksi sehingga turut meningkatkan pendapatan petani. Memiliki lahan pekarangan menjadi syarat mengikuti program ini, karena dengan luas lahan yang dimiliki maka responden juga akan memperhitungkan kebutuhan dan kendala apa saja yang akan dihadapi. Sehingga responden dapat memperhitungkan kesesuaian antara keadaan ekonomi, lahan pekarangan yang dimiliki serta keadaan sosial dimana mereka tinggal. Sebaliknya luas lahan yang sempit akan mempengaruhi tingkat persepsi petani mengenai tingkat kerumitan yang akan dihadapi, sehingga bagi petani yang hanya memiliki luas lahan sedikit cenderung kurang tertarik dan kurang merasa cocok untuk menerapkan program SL-PTT .

4. Konsumsi media

Konsumsi media diukur dari jumlah jam yang digunakan untuk mengkonsumsi/mengakses media. Penelitian ini juga menyangkut tingkatan seberapa sering petani menggunakan media massa yang dimilikinya untuk mencari informasiinformasi seputar masalah pertanian.

Tabel 4. Jumlah jam yang digunakan petani untuk mengkonsumsi media massa setiap minggu

\begin{tabular}{|c|c|c|c|}
\hline No & Keterangan & $\begin{array}{l}\text { Jumlah } \\
\text { (orang) }\end{array}$ & $\begin{array}{l}\text { Frekuensi } \\
(\%)\end{array}$ \\
\hline 1 & $\begin{array}{l}>6 \text { jam } \\
\text { (tinggi) }\end{array}$ & 49 & 54,4 \\
\hline 2 & $\begin{array}{l}2-5 \text { jam } \\
\text { (sedang) }\end{array}$ & 36 & 40,0 \\
\hline 3 & $\begin{array}{l}<2 \text { jam } \\
\text { (rendah) }\end{array}$ & 5 & 5,6 \\
\hline & Total & 90 & 100,0 \\
\hline
\end{tabular}

Sumber: Hasil penelitian, data diolah (2015)

Data di atas menunjukkan jumlah jam yang digunakan petani untuk mengkonsumsi media massa setiap minggu termasuk kategori tinggi yakni > 6 jam $(54,4 \%)$, selanjutnya $2-5$ 
jam $(40,0 \%)$ dan paling rendah $<2$ jam $(5,6 \%)$. Hal ini berarti bahwa petani di Kecamatan Kerkap termasuk golongan yang rajin dan kreatif serta banyak memanfaatkan beragam sumber informasi, seperti media massa, lembaga pendidikan, lembaga penelitian, tokoh masyarakat dan lain-lain. Semakin sering petani mengakses informasi di media massa seperti tentang informasi penggunaan bibit unggul dalam pertanian maka semakin tinggi pula persepsi dan kepercayaan petani untuk menggunaan bibit unggul yang dianjurkan dalam program SLPTT. Berbeda dengan golongan masyarakat yang tergolong pasif karena pada umumnya mereka hanya memanfaatkan informasi dari tokoh-tokoh setempat dan relatif sedikit memanfaatkan informasi dari media massa.

Tabel 5. Jenis media yang dimiliki oleh petani dalam mencari informasi seputar pertanian

\begin{tabular}{|c|c|c|c|}
\hline No & Keterangan & $\begin{array}{c}\text { Jumlah } \\
\text { (orang) }\end{array}$ & $\begin{array}{c}\text { Frekuensi } \\
(\%)\end{array}$ \\
\hline 1 & $\begin{array}{l}\text { Televisi + Radio + } \\
\text { Brosur }\end{array}$ & 27 & 30,0 \\
\hline 2 & $\begin{array}{l}\text { Televisi + Radio + } \\
\text { Brosur + Koran }\end{array}$ & 23 & 25,6 \\
\hline 3 & $\begin{array}{l}\text { Televisi + Radio + } \\
\text { Brosur + Koran + } \\
\text { Video }\end{array}$ & 19 & 21,1 \\
\hline 4 & $\begin{array}{l}\text { Televisi + Radio + } \\
\text { Brosur + Koran + } \\
\text { Video + Internet }\end{array}$ & 21 & 23,3 \\
\hline \multicolumn{2}{|c|}{ Total } & 90 & 100,0 \\
\hline
\end{tabular}

Sumber: Hasil penelitian, data diolah (2015)

Data diatas menunjukkan jenis media yang paling banyak digunakan petani dalam mencari informasi seputar pertanian adalah televisi, radio, dan brosur sebanyak 27 orang $(30,0 \%)$. Petani yang aktif dalam mencari informasi seputar pertanian akan memperoleh pengetahuan dan wawasan yang lebih, apalagi didukung oleh televisi, radio, dan brosur yang rata-rata petani memilikinya. Petani memiliki alasan untuk memilih media yang paling sering mereka gunakan ini karena selain mudah dijangkau, dan tidak menyita waktu. Hal ini menunjukkan bahwa golongan yang aktif biasanya banyak memanfaatkan beragam sumber informasi, seperti media massa, lembaga pendidikan, lembaga penelitian, tokoh masyarakat dan lain-lain. Golongan masyarakat yang aktif mencari informasi dan ide-ide baru biasanya berwawasan lebih luas dan lebih aktif terlibat dalam kegiatan penyuluhan.

5. Frekuensi mengikuti penyuluhan

$$
\text { Frekuensi petani mengikuti }
$$
penyuluhan dilihat dari seberapa sering petani bertemu dengan penyuluh. Berikut penjelasan jawaban responden mengenai indikatorindikator frekuensi penyuluhan:

Tabel 6. Frekuensi mengikuti penyuluhan

\begin{tabular}{|c|l|c|c|}
\hline No & Keterangan & $\begin{array}{c}\text { Jumlah } \\
\text { (orang) }\end{array}$ & $\begin{array}{c}\text { Frekuensi } \\
(\%)\end{array}$ \\
\hline 1 & Jarang & 14 & 15,6 \\
\hline 2 & Cukup sering & 23 & 25,6 \\
\hline 3 & Sering & 53 & 58,9 \\
\hline \multicolumn{2}{|c|}{ Total } & 90 & 100,0 \\
\hline
\end{tabular}

Sumber: Hasil penelitian, data diolah (2015)

Dari tabel 5.7 dijelaskan bahwa mayoritas responden $58,9 \%$ sering mengikuti penyuluhan, sebanyak $25,6 \%$ responden cukup sering dan $15,6 \%$ responden jarang mengikuti penyuluhan. Dalam pendidikan non formal seperti penyuluhan, maka akan disajikan materi-materi yang berkaitan dengan kegiatan SL-PTT seperti bibit yang diperoleh masingmasing responden. Semakin sering petani mengikuti penyuluhan, maka petani akan semakin mengerti dan memahami informasi yang diberikan. Selain itu, melalui penyuluhan maka pengetahuan, keterampilan, dan pengalaman dapat bertambah.

\section{Efektivitas komunikasi}

Konsep efektivitas komunikasi penyuluhan pertanian dalam program SL- PTT di Kecamatan Kerkap Kabupaten Bengkulu 
Utara diukur dengan 5 tanda efektivitas komunikasi Tubbs dan Moss. Adapun hasil

\section{Tabel 7. Efektivitas komunikasi}

\begin{tabular}{|c|c|c|c|}
\hline No & Item Pertanyaan & Jml & $\begin{array}{c}\text { Rata- } \\
\text { rata }\end{array}$ \\
\hline 1 & $\begin{array}{l}\text { Saya mengerti tentang } \\
\text { materi } \\
\text { program SL-PTT dari awal } \\
\text { sampai akhir kegiatan }\end{array}$ & 284 & 3,16 \\
\hline 2 & $\begin{array}{lr}\text { Saya } & \text { bersedia jika } \\
\text { diberikan } & \text { kesempatan } \\
\text { untuk } & \text { menyampaikan } \\
\text { pendapat pada kegiatan } \\
\text { penyuluhan }\end{array}$ & 304 & 3,38 \\
\hline 3 & $\begin{array}{l}\text { Saya paham apa yang } \\
\text { sudah dipraktekkan } \\
\text { penyuluh seperti tentang } \\
\text { pemanfaatan limbah untuk } \\
\text { pembuatan pupuk kompos } \\
\text { dapat saya lakukan }\end{array}$ & 294 & 3,27 \\
\hline 4 & 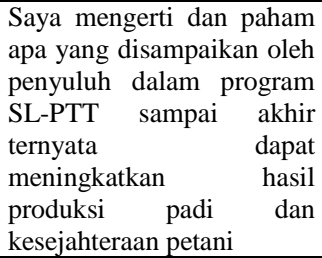 & 281 & 3,12 \\
\hline 5 & 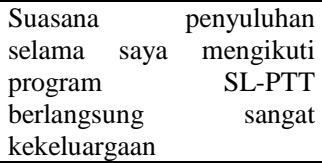 & 289 & 3,21 \\
\hline 6 & $\begin{array}{l}\text { Cara penyampaian materi } \\
\text { dari penyuluh membuat } \\
\text { perasaan saya menjadi } \\
\text { senang untuk menerapkan } \\
\text { SL-PTT }\end{array}$ & 288 & 3,30 \\
\hline 7 & $\begin{array}{l}\text { Saya senang bisa dekat dan } \\
\text { akrab dengan penyuluh } \\
\text { meskipun di luar kegiatan } \\
\text { penyuluhan }\end{array}$ & 289 & 3,21 \\
\hline 8 & \begin{tabular}{l}
\multicolumn{3}{l}{ Selama mengikuti SL-PTT, } \\
penyuluh selalu terbuka \\
dengan petani dalam \\
diskusi masalah pertanian
\end{tabular} & 301 & 3,34 \\
\hline 9 & $\begin{array}{l}\text { Cara penyampaian isi } \\
\text { pesan penyuluhan } \\
\text { membuat saya merasa } \\
\text { tertarik untuk menerapkan } \\
\text { program SL-PTT }\end{array}$ & 293 & 3,26 \\
\hline 10 & $\begin{array}{l}\text { Salah satu pesan penyuluh } \\
\text { dalam SL-PTT untuk } \\
\text { menerapkan sistem tanam } \\
\text { padi legowo, membuat } \\
\text { saya tertarik untuk } \\
\text { mencobanya }\end{array}$ & 295 & 3,28 \\
\hline 11 & $\begin{array}{l}\text { Isi pesan dari penyuluh } \\
\text { cocok dan menarik dengan } \\
\text { kebutuhan kelompok tani } \\
\text { sehingga mempengaruhi } \\
\text { sikap saya untuk } \\
\text { menerapkan SL-PTT }\end{array}$ & 293 & 3,26 \\
\hline
\end{tabular}

pengukuran yang dilakukan dapat dirangkum seperti pada tabel berikut:

\begin{tabular}{|c|c|c|c|}
\hline No & Item Pertanyaan & $\mathbf{J m l}$ & $\begin{array}{c}\text { Rata- } \\
\text { rata }\end{array}$ \\
\hline 12 & $\begin{array}{l}\text { Kegiatan praktek SL-PTT } \\
\text { ternyata mempengaruhi } \\
\text { sikap saya kedepan untuk } \\
\text { tetap } \\
\text { meskipun program sudah } \\
\text { berakhir }\end{array}$ & 291 & 3,23 \\
\hline 13 & $\begin{array}{l}\text { Setelah } \\
\text { sosialisasi pengikuti } \\
\text { saya memutuskan untuk } \\
\text { ikut bergabung dalam } \\
\text { kegiatan program SL-PTT }\end{array}$ & 294 & 3,27 \\
\hline 14 & $\begin{array}{l}\text { Muncul perasaan saling } \\
\text { percaya dengan penyuluh } \\
\text { setelah saya ikut dalam } \\
\text { kegiatan SL-PTT }\end{array}$ & 300 & 3,33 \\
\hline 15 & 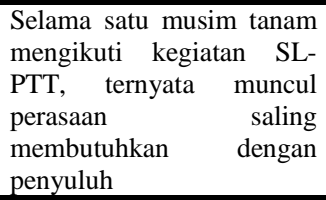 & 288 & 3,20 \\
\hline 16 & $\begin{array}{l}\text { Terciptanya hubungan } \\
\text { yang harmonis dengan } \\
\text { penyuluh baik di dalam } \\
\text { maupun di luar kegiatan } \\
\text { penyuluhan }\end{array}$ & 291 & 3,23 \\
\hline 17 & $\begin{array}{l}\text { Saya merasakan perubahan } \\
\text { tindakan kearah yang lebih } \\
\text { baik setelah mengikuti } \\
\text { penyuluhan SL-PTT }\end{array}$ & 295 & 3,28 \\
\hline 18 & $\begin{array}{lrr}\text { Setelah } & \text { mengerti } & \text { semua } \\
\text { materi } & \text { SL-PTT } & \text { dari } \\
\text { penyuluh } & \text { saya } & \text { bertindak } \\
\text { langsung } & & \text { untuk } \\
\text { menerapkan } & \text { cara } \\
\text { pemupukan padi yang baik }\end{array}$ & 281 & 3,12 \\
\hline 19 & $\begin{array}{l}\text { Saya patuh dan hormat } \\
\text { dengan apa yang sudah } \\
\text { disampaikan penyuluh } \\
\text { untuk saya aplikasikan } \\
\text { selamanya }\end{array}$ & 275 & 3,06 \\
\hline \multirow[t]{2}{*}{20} & $\begin{array}{l}\text { Saya akan terus menerus } \\
\text { untuk menerapkan materi } \\
\text { yang sudah disampaikan } \\
\text { penyuluh } \\
\text { program SL-PTT telah } \\
\text { berakhir }\end{array}$ & 233 & 2,59 \\
\hline & Jumlah & 5759 & 3,20 \\
\hline
\end{tabular}

Sumber: Hasil penelitian, data diolah (2015) Keterangan:

$$
\begin{array}{ll}
1,00-1,75 & =\text { Sangat Tidak Efektif } \\
1,76-2,50 & =\text { Tidak Efektif } \\
2,51-3,25 & =\text { Cukup Efektif } \\
3,26-4,00 & =\text { Efektif }
\end{array}
$$


Berdasarkan tabel 5.7 diketahui jumlah rata-rata efektivitas komunikasi sebesar 3,20. Jika dilihat pada penilaian yang telah dibuat sebelumnya, maka 3,20 terletak diantara 2,51 - 3,25 dengan kategori cukup efektif. Artinya secara keseluruhan komunikasi antara penyuluh dengan petani dalam program SL-PTT adalah cukup efektif. Bobot tertinggi responden terdapat pada pertanyaan nomor dua dengan nilai rata-rata sebesar 3,38 , pertanyaan ini menyebutkan "Saya bersedia jika diberikan kesempatan untuk menyampaikan pendapat pada kegiatan penyuluhan". Hal ini mengindikasikan tingginya keinginan responden untuk menyampaikan pendapat kepada tenaga penyuluhan karena mereka merasa tertarik pada materi yang disampaikan penyuluh. Pertanyaan dengan bobot terendah terdapat pada pertanyaan nomor dua puluh dengan nilai rata-rata sebesar 2, 59. Pertanyaan ini menyebutkan "Saya akan terus menerus untuk menerapkan materi yang sudah disampaikan penyuluh walaupun program SL-PTT telah berakhir". Hal ini mengindikasikan bahwa, masih ada petani yang tidak menerapkan program SLPTT yang artinya bahwa materi penyuluhan yang didapat selama mengikuti program SLPTT belum diterapkan seluruhnya oleh petani karena masih ada petani yang meragukan dan curiga terhadap apa yang disampaikan oleh penyuluh. Responden memiliki pemahaman yang berbeda dengan penyuluh, sehingga mereka cenderung memikirkan tingkat kerumitan dan efek yang akan ditimbulkan ketimbang melanjutkan anjuran penyuluh karena menurut mereka program tersebut membutuhkan waktu lebih lama dan biaya lebih besar.

Taraf signifikan pada penelitian ini $\alpha=1 \%$, dengan cara menghitung $\mathrm{X}^{2}{ }_{\text {hitung }}$ melalui rumus chi-square. Dari hasil perhitungan chi-square didapat hasil:
Nilai $X^{2}{ }_{\text {hitung }}$ sebesar 46,066 Untuk nilai $\mathrm{X}_{\text {tabel }}^{2}(2 ; 0.01)$ Dengan $\mathrm{n}=3, \alpha=1 \% \mathrm{db}=\mathrm{n}-1=3$ $1=2$ jadi nilai $X^{2}$ tabel (2;0.01) sebesar 9,21. Ternyata $X^{2}$ hitung $=46,066>X_{\text {tabel }}^{2}=9,21$.

Keputusan:

Karena $X^{2}$ hitung $>X_{\text {tabel }}^{2}$ maka Ho ditolak, sehingga keputusannya adalah proporsi efektivitas komunikasi petani adalah tidak sama. Hal ini berarti bahwa efektivitas komunikasi antara penyuluh dengan petani adalah cukup efektif, namun secara proporsinya berbeda-beda.

\section{Hubungan Karakteristik Petani dengan Efektivitas Komunikasi \\ Hubungan umur dengan efektivitas komunikasi}

Untuk melihat hubungan usia petani dengan efektivitas komunikasi antara penyuluh dengan petani menggunakan uji chi-square. Berikut hasil pengolahan dan perhitungan data dengan menggunakan program SPSS.

\section{Tabel 8. Hubungan umur dengan efektivitas komunikasi}

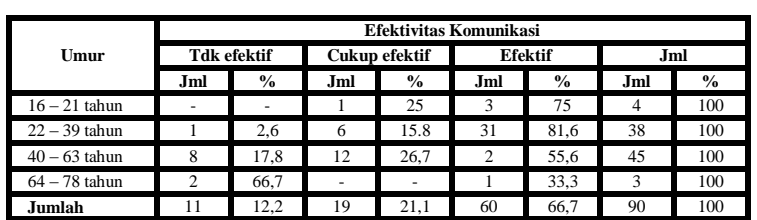

Sumber: Hasil penelitian, data diolah (2015)

Berdasarkan tabel di atas dapat dijelaskan bahwa dari 45 responden berusia 40-63 tahun: 25 responden memiliki komunikasi efektif, 12 responden memiliki komunikasi cukup efektif dan 8 responden memiliki komunikasi tidak efektif (sebanyak 8 responden yang berumur 40-63 tahun tidak mau menerapkan SL-PTT karena tidak sepaham dengan penyuluh dan responden lainnya yang berumur sama). 
Dari 38 responden dengan usia antara 22 39 tahun: 31 responden memiliki komunikasi efektif, 6 responden memiliki komunikasi cukup efektif dan 1 responden memiliki komunikasi tidak efektif, sedangkan 4 responden berusia antara 16-21 tahun, sebanyak 3 orang memiliki komunikasi efektif dan 1 responden dengan komunikasi cukup efektif. Dari 3 responden berusia antara 64-78 tahun: 1 responden memiliki komunikasi efektif, 2 responden memiliki komunikasi tidak efektif. Hasil uji chi-square diperoleh $\mathrm{X}^{2}{ }_{\text {hitung }}$ sebesar 16, 233. Chi-square tabel untuk tingkat kepercayaannya $95 \%$ adalah 12,592 . Dengan demikian $\mathrm{X}^{2}$ hitung lebih besar dari $\mathrm{X}^{2}$ tabel ( $16,233>12,592)$ ini menunjukkan bahwa $\mathrm{H}_{0}$ ditolak, artinya terdapat hubungan yang signifikan antara umur dengan efektivitas komunikasi (hasil chi-square terlampir).

Tabel 9. Hubungan tingkat pendidikan dengan efektivitas komunikasi

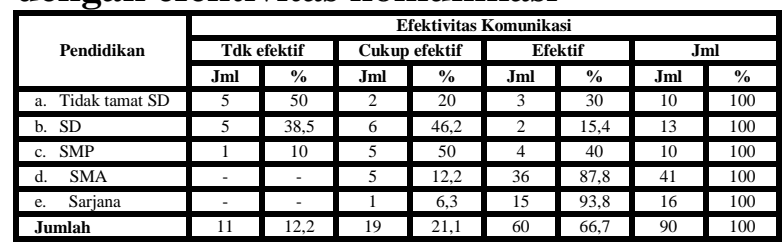

Sumber: Hasil penelitian, data diolah (2015)

Berdasarkan tabel di atas dapat dijelaskan, dari 10 responden tidak tamat $\mathrm{SD}$, terdapat 5 responden memiliki komunikasi tidak efektif, 2 responden memiliki komunikasi cukup efektif dan 3 responden memiliki komunikasi efektif. Dari 13 responden berpendidikan SD, ada 5 responden memiliki komunikasi tidak efektif, 6 responden memiliki komunikasi cukup efektif dan 2 responden memiliki komunikasi efektif. Dari 10 responden berpendidikan SMP, ada 5 responden memiliki komunikasi cukup efektif dan 4 responden memiliki komunikasi efektif. Dari
41 responden berpendidikan SMA, terdapat 5 responden yang memiliki komunikasi cukup efektif dan 36 responden memiliki komunikasi efektif. Dan dari 6 responden berpendidikan sarjana, terdapat 1 responden yang memiliki komunikasi cukup efektif dan 15 responden memiliki komunikasi efektif. Hasil uji chi-square diperoleh $\mathrm{X}^{2}$ hitung sebesar 49, 766. Chi-square tabel untuk tingkat kepercayaannya 95\% adalah 15,507. Dengan demikiaan $\mathrm{X}^{2}$ hitung lebih besar dari $\mathrm{X}^{2}$ tabel $(49,766>15,507)$. Ini menunjukkan bahwa $\mathrm{H}_{0}$ ditolak, artinya terdapat hubungan yang signifikan antara tingkat pendidikan dengan efektivitas komunikasi penyuluhan pertanian.

\section{Hubungan luas lahan dengan efektivitas komunikasi}

Hasil uji chi-square hubungan antara luas lahan dengan efektivitas komunikasi:

\section{Tabel 10. Hubungan luas lahan dengan efektivitas komunikasi}

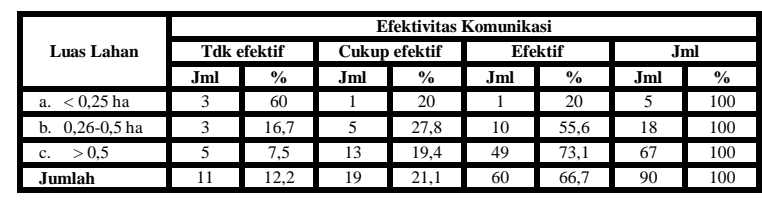

Sumber: Hasil penelitian, data diolah (2015

Berdasarkan tabel di atas dapat dijelaskan bahwa dari 5 responden dengan kepemilikan lahan seluas $<0,25$ ha, terdapat 3 responden yang memiliki komunikasi tidak efektif, 1 responden memiliki komunikasi cukup efektif dan 1 responden memiliki komunikasi efektif. Sebanyak 19 responden yang memiliki lahan antara 0,26-0,5 ha, terdapat 3 responden yang memiliki komunikasi tidak efektif, 5 responden memiliki komunikasi cukup efektif dan 10 responden memiliki komunikasi efektif dan 
dari 67 responden yang memiliki lahan antara lebih dari 0,5 ha, terdapat 5 responden yang memiliki komunikasi tidak efektif, 13 responden memiliki komunikasi cukup efektif dan 49 responden memiliki komunikasi efektif. Hasil uji chi-square diperoleh $\mathrm{X}^{2}$ hitung sebesar 13,733 . chisquare tabel untuk tingkat kepercayaannya $95 \%$ adalah 9,488 . Dengan demikian $\mathrm{X}^{2}$ hitung lebih besar dari $\mathrm{X}^{2}$ tabel $(13,733>9,488)$. Ini menunjukkan bahwa $\mathrm{H}_{0}$ ditolak, artinya terdapat hubungan yang signifikan antara luas lahan dengan efektivitas komunikasi penyuluhan pertanian (hasil chi-square terlampir).

\section{Hubungan konsumsi media dengan efektivitas komunikasi}

Berikut hasil uji chi-square hubungan antara konsumsi media dengan efektivitas komunikasi penyuluh dan petani:

Tabel 11. Hubungan konsumsi media dengan efektivitas komunikasi

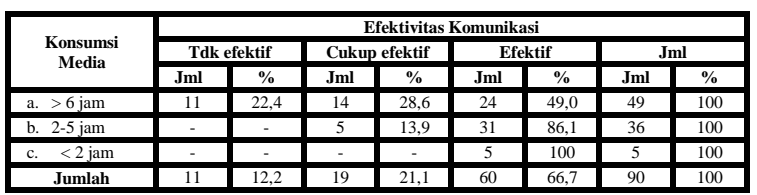

Sumber: Hasil penelitian, data diolah (2015)

Berdasarkan tabel di atas dapat dijelaskan bahwa dari 49 responden dengan konsumsi media > 6 jam seminggu, terdapat 11 responden yang memiliki komunikasi tidak efektif, 14 responden memiliki komunikasi cukup efektif dan 24 responden memiliki komunikasi efektif. Sebanyak 36 responden dengan konsumsi media 2-5 jam perminggu, terdapat 5 responden memiliki komunikasi cukup efektif dan 31 responden memiliki komunikasi efektif dan dari 5 responden dengan konsumsi media kurang dari 2 jam perminggu, ada 5 responden yang memiliki komunikasi efektif. Hasil uji chi-square diperoleh $\mathrm{X}^{2}$ hitung sebesar 17,615. Chi-square tabel untuk tingkat kepercayaannya $95 \%$ adalah 9,488. Dengan demikian $X^{2}$ hitung lebih besar dari $X_{\text {tabel }}^{2}(17,615>9,488)$. Ini menunjukkan bahwa $\mathrm{H}_{0}$ ditolak, artinya terdapat hubungan yang signfikan antara konsumsi media dengan efektivitas komunikasi (hasil chi-square terlampir).

$\begin{array}{lcc}\begin{array}{l}\text { Hubungan } \\ \text { penyuluhan }\end{array} & \begin{array}{c}\text { frekuensi } \\ \text { dengan }\end{array} & \begin{array}{l}\text { mengikuti } \\ \text { efektivitas }\end{array} \\ \text { komunikasi } & & \end{array}$

Berikut hasil uji chi-square hubungan antara frekuensi mengikuti penyuluhan dengan efektivitas komunikasi:

Tabel 12. Hubungan frekuensi mengikuti penyuluhan dengan efektivitas komunikasi

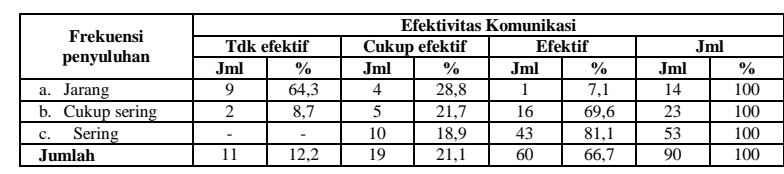

Sumber: Hasil penelitian, data diolah (2015)

Berdasarkan tabel di atas dapat dijelaskan bahwa dari 14 responden yang jarang mengikuti penyuluhan, terdapat 9 responden yang memiliki komunikasi tidak efektif, 4 responden memiliki komunikasi cukup efektif dan 1 responden memiliki komunikasi efektif. Dari 23 responden yang cukup sering mengikuti penyuluhan, terdapat 2 responden memiliki komunikasi tidak efekttif, 5 responden memiliki komunikasi cukup efektif dan 16 responden memiliki komunikasi efektif. Dari 53 responden yang sering mengikuti penyuluhan, ada 10 responden yang memiliki komunikasi cukup efektif dan 43 responden memiliki komunikasi efektif. Hasil uji chi-square diperoleh $X^{2}$ hitung sebesar 47,393. Chisquare tabel untuk tingkat kepercayaannya 95\% adalah 9,488. Dengan demikian $X^{2}$ hitung lebih besar dari $\mathrm{X}_{\text {tabel }}^{2}(47,393>9,488)$ . Ini menunjukkan bahwa $\mathrm{H}_{0}$ ditolak, artinya terdapat hubungan yang signifikan antara 
frekuensi mengikuti penyuluhan dengan efektivitas komunikasi pertanian (hasil chisquare terlampir).

\section{Pembahasan}

Efektivitas komunikasi penyuluhan di Kecamatan Kerkap Kabupaten Bengkulu Utara yang diukur melalui lima tanda efektivitas komunikasi Tubbs dan Moss yaitu pengertian, kesenangan, mempengaruhi sikap, hubungan sosial yang baik dan tindakan, berdasarkan indikator tersebut dapat disimpulkan bahwa efektivitas komunikasi antara penyuluh dengan petani tergolong cukup efektif, dimana nilai ratarata perolehan data efektivitas komunikasi sebesar 3,20 terletak pada skala penilaian antara 2,51 - 3,25 dengan kategori cukup efektif. Schramm (1973: 101) menyebutkan bahwa efektivitas komunikasi ditunjukkan oleh kondisi saling melengkapi antara komunikan secara umum dengan penggunaan media komunikasi dalam mengantarkan suatu perubahan. Pengujian hipotesis menunjukkan bahwa umur berhubungan signifikan dengan efektivitas komunikasi, dimana nilai $\mathrm{X}^{2}{ }_{\text {hitung }}>\mathrm{X}_{\text {tabel }}^{2}$ $(16,233>12,592)$ artinya hipotesis awal yang menyatakan terdapat hubungan signifikan antara umur dengan efektivitas komunikasi dapat terbukti.. Umur responden merupakan usia responden. Umur berhubungan dengan kemampuan dan semangat sehingga mereka mau mengikuti penyuluhan dan mampu memahami pesan yang disampaikan penyuluh. Hal ini akan menimbulkan pengertian terhadap anjuran penyuluh sehingga mereka merasa tertarik untuk mengikuti program SL-PTT. Menurut Rona (1999: 89), orang yang masuk pada golongan tua cenderung selalu bertahan dengan nilai-nilai yang lama sehingga diperkirakan sulit menerima hal-hal yang bersifat baru. Orang yang berusia lebih tua mempunyai partisipasi yang lebih rendah dibandingkan dengan yang berusia muda.. Petani yang berusia lanjut yaitu berumur 65 tahun ke atas biasanya fanatik terhadap tradisi dan sulit untuk diberikan pengertianpengertian yang dapat mengubah cara berpikir, cara kerja dan cara hidup. Mereka cenderung bersikap apatis terhadap adanya teknologi baru sehingga mereka hanya melaksanakan kegiatan yang sudah biasa diterapkan oleh pendahulu atau masyarakat sekitar.

Pengujian hipotesis menunjukkan bahwa tingkat pendidikan berhubungan signifikan dengan efektivitas komunikasi, dimana nilai $X^{2}$ hitung $>X_{\text {tabel }}^{2}(49,766>$ $15,507)$ itu artinya hipotesis awal yang menyatakan terdapat hubungan antara tingkat pendidikan dengan efektivitas komunikasi dapat terbukti. Hal inilah yang menyebabkan mereka lebih memilih untuk menerapkan program SL-PTT. Sebaliknya mereka yang berpendidikan rendah memilih untuk bertahan pada cara tradisional karena mereka kurang merasa senang dan cocok dengan cara bertani modern yang dianjurkan oleh penyuluh dalam program SL-PTT karena menurut mereka bertani modern jauh lebih rumit. Selain itu juga karena mereka mempertimbangkan adanya resiko di kemudian hari. Tinggi rendahnya pendidikan petani akan menanamkan sifat yang menuju penggunaan praktek pertanian yang lebih modern. Mereka yang berpendidikan tinggi relatif lebih cepat dalam melakukan anjuran penyuluh. Tingkat pendidikan yang rendah pada umumnya kurang menyenangi perubahan sehingga sikap mental untuk menambah pengetahuan khususnya ilmu pertanian kurang. Menurut Hasyim (2006), tingkat pendidikan formal yang dimiliki petani akan menunjukkan tingkat pengetahuan serta wawasan yang luas untuk petani menerapkan apa yang diperolehnya untuk peningkatan usaha taninya. Menurut Saridewi (2010), tingkat pendidikan seseorang dapat mengubah pola pikir, daya penalaran yang lebih baik, sehingga makin 
lama seseorang mengenyam pendidikan akan semakin rasional.

Luas lahan berhubungan signifikan dengan efektivitas komunikasi, dimana nilai $\mathrm{X}^{2}{ }_{\text {hitung }}$ $>\mathrm{X}_{\text {tabel }}(13,733>9,488)$ itu artinya hipotesis awal yang menyatakan terdapat hubungan antara luas lahan dengan efektivitas komunikasi dapat terbukti. Menurut Hermanto (1993:65) luas lahan usahatani menentukan pendapatan, taraf hidup dan derajat kesejahteraan rumah tangga petani. Luas penguasaan lahan akan berpengaruh terhadap keinginan petani untuk menerapkan, karena semakin luas lahan usahatani maka akan semakin tinggi hasil produksi sehingga turut meningkatkan pendapatan petani. Jadi luas lahan harus terlebih dahulu dapat meningkatkan pendapatan petani untuk kemudian petani dapat semakin cepat melakukan perubahan dan mengikuti penyuluhan, karena memiliki kemampuan ekonomi yang lebih baik.

Konsumsi media berhubungan signifikan dengan efektivitas komunikasi, dimana nilai $\mathrm{X}^{2}{ }_{\text {hitung }}>\mathrm{X}_{\text {tabel }}{ }(17,615>$ 9,488 ) itu artinya hipotesis awal yang menyatakan terdapat hubungan antara konsumsi media dengan efektivitas komunikasi dapat terbukti. Golongan yang kreatif biasanya banyak memanfaatkan beragam sumber informasi. Berbeda dengan golongan masyarakat yang kurang kreatif umumnya hanya memanfaatkan informasi dari tokoh-tokoh setempat dan relatif sedikit memanfaatkan informasi dari media massa. Disamping itu, golongan masyarakat yang aktif mencari informasi dan ide-ide baru biasanya lebih inovatif dibanding orangorang yang pasif apalagi yang selalu keptis (tidak percaya) terhadap sesuatu yang baru (Mardikanto, 1993). Seiring dengan kebiasaan mereka yang mengkonsumsi media maka turut mempengaruhi hubungan sosial yang baik diantara petani dengan penyuluh karena petani sedikit banyaknya mendapat informasi dari penyuluh dan mereka dapat bertukar pikiran baik di dalam penyuluhan maupun diluar penyuluhan pertanian.

Pengujian hipotesis bahwa frekuensi mengikuti penyuluhan berhubungan dengan efektivitas komunikasi, dimana $\mathrm{X}^{2}{ }_{\text {hitung }}>$ $X^{2}$ tabel $(47,393>9,488)$ itu artinya hipotesis awal yang menyatakan terdapat hubungan antara frekuensi mengikuti penyuluhan dengan efektivitas komunikasi dapat terbukti. Semakin tinggi frekuensi petani mengikuti penyuluhan maka keberhasilan penyuluhan pertanian yang disampaikan semakin tinggi pula. Sehingga komunikasi dapat berlangsung cukup efektif. Frekuensi petani dalam mengikuti penyuluhan yang meningkat disebabkan karena penyampaian yang menarik dan tidak membosankan serta yang disampaikan benar-benar bermanfaat bagi petani dan usahataninya (Hasyim, 2003: $60)$.

\section{PENUTUP \\ Simpulan}

Berdasarkan hasil penelitian dan pembahasan yang telah dilakukan sebelumnya, maka penelitian ini dapat disimpulkan sebagai berikut:

1. Efektivitas komunikasi penyuluhan pertanian dalam program SL-PTT di Kecamatan Kerkap Kabupaten Bengkulu Utara tergolong cukup efektif.

2. Umur berhubungan signifikan dengan efektivitas komunikasi antara penyuluh dengan petani

3. Tingkat pendidikan berhubungan signifikan dengan efektivitas komunikasi antara penyuluh dengan petani

4. Luas lahan berhubungan signifikan dengan efektivitas komunikasi antara penyuluh dengan petani

5. Konsumsi media berhubungan signifikan dengan efektivitas komunikasi antara penyuluh dengan petani

6. Frekuensi mengikuti penyuluhan berhubungan signifikan dengan 
efektivitas komunikasi antara penyuluh dengan petani

Karakteristik petani yang paling dominan berhubungan dengan efektivitas komunikasi adalah tingkat pendidikan petani dan frekuensi mengikuti penyuluhan.

\section{Saran}

1. Bagi Lembaga penyuluhan perlu memperhatikan karakteristik petani dalam berkomunikasi agar komunikasi dapat berlangsung efektif. Sebab berdasarkan hasil penelitian ini karakteristik petani seperti umur, tingkat pendidikan, luas lahan, konsumsi media, dan frekuensi mengikuti penyuluhan berhubungan signifikan dengan efektivitas komunikasi. Selain itu juga, perlu pendampingan dari penyuluh yang holistik, bersinergi, terkoordinir, terfokus dan terukur sangat diharapkan oleh semua pihak dalam mengakselerasi pencapaian dari sasaran program yang telah ditetapkan.

2. Bagi peneliti lainnya, dapat melanjutkan penelitian ini dengan menggunakan penelitian kualitatif agar masalahnya dapat digali lebih dalam lagi, dengan menggunakan karakteristik petani yang lain seperti pengalaman petani, jumlah tanggungan, budaya, perilaku petani atau bahkan program yang diberikan untuk petani.

\section{DAFTAR PUSTAKA}

Adjid. (2001). "Membangun Pertanian Modern". Jakarta: Yayasan Pengembangan Sinar Tani.

Hermanto. (1993). "Ilmu Usahatani". Jakarta: Penebar Swadaya.

Hasyim. (2006). "Community Development Berbasis Ekosistem". Jakarta: Diadit Media.

Moss, Sylvia dan Tubbs, Stewart L. (2000). "Human Communication. Prinsip- prinsip Dasar". Remaja Rosdakarya. Jakarta

"Human

Communication". Bandung:

Penerbit PT. Yayasan Andi. Mardikanto, Totok. (1993). "Bunga rampai Pembangunan Pertanian".

Surakarta: Sebelas Maret University Press.

Prasetyo, Bambang. (2010). "Metode Penelitian Kuantitatif". Jakarta:

PT. Raja Grafindo Persada.

Rinchaid, A.l. dan W. Schram. (1997). "Asas-asas Komunikasi Antar Manusia". Penerbit: LP3ES.

Sugiyono. (2009). "Statistik Untuk Penelitian". Bandung: Alfabeta.

-------.. (2011). "Statistika untuk Penelitian". Bandung: Alfabeta. (2012). "Metode Penelitian Kuantitatif, Kualitatif, dan $R \& D$ ". Bandung: Alfabeta.

Singarimbun, Masri dan Effendi, Sofian. (1995). "Metode Penelitian Survey". Jakarta: PT. Pustaka LP3ES.

Umar, Husein. (2003). "Metodologi Penelitian Aplikasi Dalam Pemasaran”. Jakarta: PT. Gramedia Pustaka Utama. 